\title{
ESSAY
}

\section{Questioning Consensus, Cultivating Conflict}

(forthcoming in Journal of Management Inquiry)

Christian De Cock and Emma L Jeanes

School of Business and Economics

University of Exeter

Streatham Court

Rennes Drive

Exeter EX4 4PU

United Kingdom

(c.de-cock@exeter.ac.uk)

(e.jeanes@exeter.ac.uk) 


\title{
Questioning Consensus, Cultivating Conflict
}

\begin{abstract}
In this essay we put into question the pre-occupation with consensus and convergence that seems to characterize the field of OMT (Organization and Management Theory). Much effort has been directed to providing a model of unification legitimating the political containment of conflictual diversity. Even potentially controversial debates (such as the 'Paradigm Wars') have taken on a rather tired quality as academics tend to look for the 'middle ground' or are happy to retreat into private language games. We suggest that we should move beyond 'bridging' or 'containment' strategies and strive for a true re-politicization of the field. This presupposes that we learn to value notions of conflict and struggle again, rather than muffling them by referring to a common 'professionalism'. In developing our argument we connect with the thinking of Mikhail Bakhtin, offering a challenge to both integration/ consensus and fragmentation/ incommensurability discourses which seem so prevalent in our field today.
\end{abstract}




\section{Questioning Consensus, Cultivating Conflict}

To set us on our way, three epigraphs:

OMT seems to be having a hiccup about the legitimacy of the scientific method and knowledge. Instead of building scientific knowledge that better approximates reality, we are building more and more paradigms without a means for reconciling them. (Van de Ven, 1999, p.119)

The diversity of organizational theory and the range of ideas about how to develop organizational theory increased dramatically during the [past] decade... There has been vigorous and unresolved debate about whether such diversity is healthy for the field. There is far more consensus, however, that more integration of these varied ideas would help move the field forward. (Elsbach, Sutton \& Whetten, 1999, p.627, editorial of an AMR special issue on theory development, emphasis added)

I take it that these are the most important questions which we confront. How to deal with and fend off the simplicities implicit in a world in which: 'Have theory, will travel' makes for easy intellectual and political progress. How to resist the singularities so commonly performed in the acts of naming and knowing. How to defy the overwhelming pressures on academic production to render knowing simple, transparent, singular, formulaic. How to resist the pressure to enact, yet again, the God-trick ${ }^{1}$. (Law, 1999, p.11)

\section{Introduction}

These epigraphs, expressing contradictory concerns, seem to resonate with the professional reality of all of us organizational scholars in recent years. What exactly are we trying to achieve when we conduct fieldwork, write academic articles, act as consultants, or teach students? Many organizational scholars will admit to pangs of anxiety when addressing some (or all) of these once innocent sounding questions. We see this anxiety manifesting itself in various, interrelating ways. These include the increasingly problematic relation between academics and practitioners, the proliferation of ontological and epistemological positions, and the pre-occupation with relations and practices within the community of researchers.

\footnotetext{
${ }^{1}$ The 'god trick' was defined by Jacques (1992, p.594) as “the invisible power of seeing everything without the corresponding responsibility to acknowledge the social/cultural/historical site from which one is viewing."
} 
The knowledge-practice antinomy, while lamented for many years, became especially pertinent from the early 1990s onwards. As it appeared increasingly obvious that the body of knowledge published in academic journals had practically no audience in business or government (Daft \& Lewin, 1990), the number of special forums and journal editions devoted to the topic of research relevance and utilization increased significantly (Rynes, Bartunek \& Daft, 2001; British Journal of Management - special edition, 2001), and the gap between academics and practitioners became a prominent topic in Academy of Management presidential addresses (Hambrick, 1994; Huff, 2000; Mowday, 1997). The encounter with a body of writing rooted in the distinctive preoccupations and manners of proceeding of Continental European philosophy, initially under the labels of postmodernism or post-structuralism (Chia, 1996, Kilduff \& Mehra, 1997; Parker, 1992), started to affect (some would argue 'infect') the field of organization studies from the early 1990s onwards, making the settled view of "building scientific knowledge that better approximates reality” (Van de Ven, 1999, p.119) look increasingly suspect. The collision between ideas derived from a not always well understood cluster of philosophical traditions and a field largely dominated by an Anglo-Saxon tradition of conducting organizational theorizing and research precipitated an 'inward' turn of the field. Suddenly it became legitimate to make the craft of researching and theorizing more explicit (Clegg \& Hardy, 1996; Weick, 1999), putting some question marks behind the nature and purpose of the field of organization studies/science ${ }^{2}$. The 'paradigm wars' and the 'Mode 1 versus Mode 2' debates became particular focus points, centering on the nature of management research and the relation between researchers and practitioners respectively. In the following sections we will explore these particular discourses and will argue that they make for far too easy intellectual and political progress anno 2004.

\footnotetext{
${ }^{2}$ It is perhaps significant that we do not even agree on a common name for our field, the terms organization studies, organization and management theory (OMT), and organization science being used interchangeably and depending on researchers' geographical location.
} 


\section{The nature and purpose of research: Paradigm wars or a search for consensus?}

Given the relative recency of this internal focus and the unexpected turbulence, one is tempted to say of the 'paradigm wars,' 'Give war a chance.' We seem to be in the midst of an active shakeout. (Weick, 1999, p.797)

Pfeffer (1993) is generally credited with re-igniting the debate over the proper direction of the organization science discipline in the United States. His argument typifies the selfreappraisal of management research that has marked the 1990s, including pointed discussions on the desirable direction of theory building and the true nature of management research (Astley \& Zammuto, 1992; Daft \& Lewin, 1990; Sutton \& Staw, 1995; Weick, 1999). Pfeffer’s (1993) position was unequivocal:

Consensus itself, however achieved, is a vital component for the advancement of knowledge in a field. Without some minimal level of consensus about research questions and methods, fields can scarcely expect to produce knowledge in a cumulative, developmental process (p.611).

Van Maanen's animated response ${ }^{3}$ to this position led Van de Ven (1999), in an ironic turn, to sketch the American version of the paradigm wars as a 'Pfefferdigm' versus 'VanMaanendom'.

It is probably fair to pinpoint Sociological Paradigms and Organizational Analysis (Burrell \& Morgan, 1979) as a starting point for a serious discussion about 'paradigms' in our field in Europe. In a reflective essay Burrell (1996) suggested that the key contribution of the book was to raise awareness that the normal state of organization science is pluralistic:

This does not mean that organizational analysis is 'immature' or is awaiting its normal science phase with bated breath. It is simply that a plurality of legitimate and competing perspectives is to be expected in all sciences but especially in the social ones (p.648).

He further argued that organization science, although it shows more of a "fractured visage” than it did thirty years ago, has never been a stranger to fractured lines of analysis. It is just that the powerful agreed to ignore fundamental problems in addressing

\footnotetext{
3 "I want to suggest here that this [Pfeffer's] sour view of our field is - to be gentle - insufferably smug; pious and orthodox; philosophically indefensible; extraordinarily naive as to how science actually works; theoretically foolish, vain and autocratic; and - still being gentle - reflective of a most out-of-date and discredited father-knows-best version of knowledge, rhetoric and the role theory plays in the life of any intellectual community.” (Van Maanen, 1995, p. 133)
} 
fundamental issues. The pervasive desire to give OMT an effective presence as a discipline meant that scientific legitimacy became identified with academic respectability and political neutrality and innocuousness ${ }^{4}$.

Whilst functionalism is no longer seen as representative of a normal science in our discipline, there still seems to exist a strong, if implicit, yearning among scholars that it will be replaced eventually and inevitably by another single approach after the period of 'revolution' we are going through. Indeed, if we were living through a true paradigm 'war' (or even a contest), it very much looks as if a mild form of 'Pfefferdigm' (reducing the purport of the field's internal disunity) is winning out in most theoretical discussions. Hardy (2002, p.17) talks about an "obsession with consensus and convergence that characterizes much of the work carried out by the Academy of Management” in this context. For example, numerous papers have been devoted to 'paradigm bridging' (e.g. Gioia \& Pitre, 1990; Lewis \& Grimes, 1999; Schultz \& Hatch, 1996; Weaver \& Gioia, 1994). Furthermore, there seems to be an emerging view that theoretical proliferation and turnover seem to generate impossible demands on scholars' ability to keep current in the field; threatening our confidence and making it difficult to determine the appropriate foundation on which to build research (Elsbach, Sutton \& Whetten, 1999; Glynn, Barr \& Dacin, 2000). Theory development forums have therefore concentrated mainly on procedural issues, integrating existing models and searching for a single conceptual framework to unify 'false' differences between various theories and paradigms. Fabian (2000), in the conclusion of an intelligent piece on 'controversy' in the management discipline, seems to catch a prevailing mood when she suggests:

...A proliferation of theoretical perspectives without any cohesion leaves researchers unable to discern the pragmatic 'what's what?' Theory again turns meaningless when constantly contradicted, disparaged, or upstaged by vying theories and paradigms (p.366).

This is not to say that the dominant tendency in OMT is to reject conflict entirely - which would be a rather remarkable feat - but rather that the inevitably conflictual process by which, through exclusion and subordination, the discipline defines its borders tends to be

\footnotetext{
${ }^{4}$ Of course, this is not distinctive of our field. Bourdieu (1988) and Culler (1981/2001) make similar points regarding their respective fields of sociology and literary theory.
} 
denied in the name of an ideal of knowledge and truth that deems these to be conflictfree, self-identical, and hence, reproducible as such and transmissible to students (cf. Weber, 2001). This theme of unification and 'correction' of interpretation is clearly demonstrated in the recent debate in this journal on the 'truth' about social constructionism. Meckler and Baillie (2003a) present a case for finding a 'middle way' between what they term 'objective truth' and the postmodern rejection of notions of truth, by distinguishing "what is correct from what is mistaken in...social construction theses" (p. 273). In his reply Gioia (2003) sets out to clarify what he sees as the common misconstrual of social constructionism (by non-interpretive theorists). Both Gioia's (2003) and Lounsbury's (2003) replies present strongly worded arguments defending social constructionism as a distinct approach, and Meckler and Baillie’s (2003b) final reply is no less forceful and personal: "It seems we have struck a raw nerve, sending such esteemed scholars as Gioia and Lounsbury howling so furiously at the moon” (p.302).

The significance of heated epistemological and ontological exchanges so typical of the 'paradigm wars' certainly should not be exaggerated when the extent to which they actually have informed our research practice is marginal ${ }^{5}$. To use Vickers' (1995) terminology: there seems to be a disjunction between the ways in which organizational scholars are ready to see and value the organizational world (their appreciative setting which can be often adventurous) and the ways in which they are ready to respond to it (their instrumental system - which tends to be rather conservative). Over the years the paradigm debate seems to have become the vessel of containment of its original political challenge, redefining the place and nature of conflict by placing it within a 'natural' context. Awkward or divergent perspectives are now all too easily packaged "as part of the so-called 'paradigm wars' [rather] than as raising questions with which mainstream organization theory has to be concerned" (Hinings and Greenwood, 2002, p.416). The personalized nature characterizing many of the 'paradigm' exchanges merely adds to this sense of irrelevance for the wider community. Both those pleading for consensus/integration, and those advocating incommensurability/fragmentation are 
effectively de-politicizing the field. Czarniawska (2001, p.19) pithily summarized the situation with a nod to Bakhtin’s vocabulary:

Recently, probably in a wave of turn-of-the-century anxiety, we have witnessed many appeals to integration and solidification, accompanied by the fears of fragmentation and a consequent loss of legitimacy of organization theory. The alternative claims vouched for chaos and fragmentation, for incommensurability and separate word games. While both integration and separation are attractive as separate discourses (they both allow one to live in peace and talk only to those who agree), I shall insist on the hardship of the paradoxical road in suggesting that talk to the Other we must, although we need not agree.

\section{Academics and practitioners: Mode 1, 2, or 1.5?}

Why do so much education and training, management consulting, and business research and so many books and articles produce so little change in what managers and organizations actually do? (Pfeffer \& Sutton, 1999, p.83)

That there is a wide gap between organizational research and managerial practice is hardly a new observation (Daft \& Lewin, 1990; Jacques, 1992; Starkey \& Madan, 2001). Findings in scholarly management journals appear, to many, only remotely related to the world of practicing managers and as a consequence the perceived impact from the research coming from business schools is close to nil (Astley \& Zammuto, 1992). Recent studies by Boland et al. (2001) and Mohrman et al. (2001) indicated that the typical way of presenting academic information (through objective, declarative knowledge) is a relatively ineffective way of getting knowledge to 'take' in practitioner settings. Furthermore, the 'knowledge gap' is felt through the frequent experience of managers that academic research follows, rather than leads, practice (Rynes, Bartunek \& Daft, 2001).

In response there have been various 'call to arms', not least in recent presidential addresses at the Academy of Management (Hambrick, 1994; Huff, 2000; Mowday, 1997, Van de Ven, 2002). Hambrick’s (1994, p.12) appeal is typical:

\footnotetext{
${ }^{5}$ Martin (1992, p.233), while reflecting on her practice as a researcher, remarked: "Those of us who have unconservative political convictions and a commitment to doing empirical organizational research have a problem: Empirical research in our field tends to be inherently conservative.”
} 
We must recognize that our responsibility is not to ourselves but to the institutions around the world that are in dire need of improved management, as well as to those individuals who seek to be the most effective managers they possibly can be.

The sub-text here is that organizational researchers must bridge the many disciplinary and ideological islands in the academic community in order to see the whole system that they are studying and so be of 'use' to a wider constituency ${ }^{6}$; with usefulness determined by whether the research findings are actually being incorporated in organization design decisions, and whether action was taken that was informed by the research (cf. Mohrman, 2001).

The increasing pressure to be less theoretically abstract and more practically relevant for private and public management seems to have crystallized in recent years around the 'Mode 1' (discipline-based and theory building) versus 'Mode 2' (collaborative and problem-focused) discourse, based on Gibbons et al.’s (1994) internationally influential research manifesto. The basic argument of this book is that as traditional disciplinary university knowledge (Mode 1) is no longer able to reflect the current complexities of the world, knowledge should be increasingly produced by tearing down boundaries between disciplines as well as between theory and practice. Applied to OMT, advocates of a Mode 2 perspective would argue that the field should by its very nature be applied, and that too many within the closed academic community produce trivial and irrelevant knowledge (Tranfield \& Starkey, 1998). Starkey and Madan (2001, p.6), for example, offer a bleak picture of organizational research that "if judged guilty of a relevance gap... it raises critical issues of role justification and, ultimately, long term survival”. Others gladly have taken up the challenge, arguing that central to the development of useful knowledge is the freedom to experiment, to produce useless knowledge that might become useful, and to enjoy the freedom from the necessity of 'relevance' as a criterion of value (Grey, 2001; March, 2000).

In an eerie replication of the 'paradigm wars,' major efforts have been undertaken to do a little ‘bridging’. Huff (2000, p.293-294), for example, suggests that "Mode 1.5 is a

\footnotetext{
${ }^{6}$ This has echoes of the English upper class view: "If only the lower orders were to forget their grievances and pull together for the good of all, much tedious turmoil could be avoided.” (Eagleton, 1996, p. 19)
} 
difficult but desirable position 'above' these modes of production..." and "business schools... can help drive forward the development of a Mode 1.5 agenda that attempts to redress the limitations of knowledge production". Even those who favor a move to Mode 2 approaches acknowledge the dilemma facing the individual choosing between 'pure' research and practitioner relevance in a context that favors the former with approval and reward, and can consider the latter with suspicion (Starkey and Madan, 2001). Others point out that it is far from clear what practitioners actually desire from academic circles or what they understand as 'relevance'. Pettigrew (2001), for example, suggests that the perception of relevance is influenced by the developments of long-term relationships between user and academic, and the credibility of academic and institution, the level to which the practitioner feels a sense of identification with the research output, and the extent to which their own ideas are reaffirmed. Weick (2001) argues that it is crucial to focus not only on the knowledge "producer", but also the knowledge "consumer":

The relevance problem is not just that academics will not set aside their disciplines and begin to work in a transdisciplinary manner. The relevance problem is also that practitioners will not set aside their fads and begin to work with fundamentals. (p. S72)

Thus the conflictual sting is quickly taken out of the dichotomy as the field tries to find a consensual position (let's split the difference, let's apportion the blame elsewhere), whilst those on the margins (the Mode 1 or Mode 2 'warriors') can happily talk amongst themselves.

\section{Relations within the community of OMT researchers}

We contend that, as the field has grown and as it has sought scientific legitimacy through adoption of many of the trappings of scientific enterprise, it has simultaneously become more rigid, more homogeneous, more self-referential, less able to embrace novelty, and hence less able to co-evolve with the world to which it is connected. (Bouchikhi \& Kimberly, 2001, p.78-79)

A key point... is that empirical evidence about the topic being addressed - not rhetorical debates nor social-political advancement - provides the answer to how, where, and when to explore and exploit OMT knowledge. (Van de Ven, 1999, p.123-124) 
The belief Van de Ven expresses in the above quote has in recent years proved to be rather idealistic. There is now a growing awareness that we as academics are involved in rather messy practice, with its own particular rules and action theories. Power-laden mechanisms of production and control (e.g. resource allocations, editorial decisions and refereeing procedures) discipline the research process and condition what is to count as ‘scientific knowledge’ (Calás \& Smircich, 1999, Westwood \& Clegg, 2003). Indeed, the research process has acquired strong commercial overtones as increasingly the expression of knowledge claims becomes economically rewarded apart from its contribution to understanding (Deetz, 1995). Bouchikhi and Kimberly (2001) suggest that there is a growing disjunction between what many management researchers would really like to do in their research and what they feel constrained to do by the existing institutional framework. The institutionalization of business education and management research has led to the development of procedures, controls and mindsets which effectively act as a sort of intellectual straitjacket. Perhaps nowhere is the intellectual straitjacket as obvious as in the pressure to publish in elite journals (Clegg, 2002; Pettigrew, 20017). This has an inevitably conservative impact on the priorities and choices of individual researchers. Sutton and Staw (1995), for example, discuss how authors' expositions of their methods often bear little resemblance to the actual processes that got them to the final published product. Against this background, Pfeffer's call to commit "to a set of fundamental questions... and working through a set of processes or rules to resolve theoretical disputes and debates (Pfeffer, 1993, p.618)” sounds a little shrill. Inquiry is alwaysalready restricted by visible and invisible rules, codes and protocols ${ }^{8}$.

Research that does not conform to the dominant speech genres and styles considered worthy of publication has little chance of ever being published. Burrell's (1996, p.652) reflection on how he found it simply impossible to publish an article on Michel Foucault,

\footnotetext{
${ }^{7}$ It is somewhat ironic that these sentiments are being expressed in articles published in elite journals, thus increasing the authors' 'strike rate'.

${ }^{8}$ One could argue that one only truly has entered a field, not when one has faithfully learned and abides by its rules, but when one practices a degree of self-distance and participates in the unwritten rules which tell us how and when to violate the explicit rules. It is this distance from the symbolic rules which truly confirms our membership. This is why the argument that more codified rules could serve as guidance for those entering the field is misleading. The more one identifies with the explicit rules, the more one is condemned to remain an outsider (Žižek, 2002).
} 
however pertinent the material to the study of organizations, is one of our favorite examples:

... in 1984, when a piece written on Foucault's contribution to organizational analysis was submitted to ASQ... I treasure its referees' comments to this day, for all three questioned the relevance of 'an unknown French philosopher' and asked 'what could an American audience learn from such thought'. My understanding of the importance of the North Atlantic Ocean as a divide as well as a communication route was firmly fixed at this moment.

Whilst mildly amusing in retrospect, this quote also crystallizes the difficulties of working within a 'professionalist' paradigm of knowledge. The regulative idea of this paradigm is that of the absolute autonomy of the individual discipline, construed as a self-contained body of investigative procedures and of knowledge, subject to its own laws (Weber, 2001). In recent years we have seen even a hardening of disciplinary boundaries and an increasing resistance of disciplines to engaging in debate with other disciplines (Clegg, 2002; Fuller, 2003) ${ }^{9}$. The danger is that such self-containment can lead to a lack of real engagement with other perspectives, with conflict being explained away by "simply asserting that it is contained by - i.e., within - whatever monad (set of assumptions, interpretive institution, etc.) is said to occupy the critic” (Weber, 2001, p.43) ${ }^{10}$. Efforts to encourage active engagement between perspectives face an almost institutionalized challenge, with the result often a passive juxtaposition of perspectives, rather than real engagement (cf. Westwood \& Clegg, 2003), or vitriolic attacks which merely serve to deepen the entrenchment of views.

\footnotetext{
9 To borrow Frost's words: despite exposure to “expansive oceans of knowledge” organizational scientists prefer to stay in their “own comfortable well” (Frost, 2002, p.21).

${ }^{10}$ Interestingly, Samuel Weber wrote these comments back in 1983 . For a review of the book containing a collection of his essays (Weber, 2001), see De Cock and Volkmann (2002).
} 


\section{A brief encounter with Bakhtin}

To bring Bakhtin to bear is to risk seeming to rehearse the tired gesture by which the Soviet theorist is burdened with the credit for having, either single-handedly or with a little help from his friends, anticipated and surpassed the most significant theoretical trends of recent decades. (Shepherd, 2001, p.136)

We have explored so far the manifold ways in which recent controversies in our discipline revolve around the issues of consensus, conflict and diversity (be it in the form of a yearning for a one-best-way-of-proceeding or, alternatively, as a denouncement of the intellectual straitjacket an institutionalized field imposes). In this context it is somewhat surprising that so little effort has been devoted to exploring the work of thinkers who have put the issue of conflict and diversity at the core of their intellectual projects. No one was more pre-occupied with the issues of conflict and diversity (particularly in relation to discourse) than the Russian literary theorist and philosopher Mikhail Bakhtin and it is to him we turn next. With Bakhtin we will take a firm step away from the market view of language (which we believe still underpins many OMT discourses) where meaning can belong to us like a commodity, and language is just a set of tokens which, like money, allow us to exchange our meaning-commodity. In Bakhtin's view language has a relative autonomy; an existence of its own in which human beings come to participate, and only by participating in it do they come to be human at all. Yet, language is also always caught up in definite social relationships, and these social relationships are in turn part of broader political, ideological and economic systems.

Whilst it is easy to deploy such characteristically Bakhtinian terms such as heteroglossia, dialogism, the carnival, or chronotope; such efforts often only serve as incantations to dignify already existing analytical habits that have not been affected by Bakhtin's thought in any meaningful way (Poole, 2001). It is worth pointing out at the start of our 'encounter', that in his several attempts to find a single name for diversity, such as heteroglossia or polyphony, Bakhtin was at pains never to stifle the energizing role of the paradox and conflict at the heart of his enterprise. We therefore turn to Bakhtin, not to 
borrow some meta-framework, but because we believe we can enrich our thinking about diversity and conflict by connecting with his.

Throughout his various writings Bakhtin charts an epic struggle over time between the forces of centralization, which he also called the centripetal forces of sociolinguistic life, and the centrifugal forces of heteroglossia. Thus there exists a contradiction-ridden, tension-filled unity of two embattled tendencies in the life of language. Bakhtin, who always opposed language becoming mechanical or authoritative, was an astute student of his own time and place, marking, for example, Pravda editorials with colored pens to bring out the hidden meanings behind the different levels of discourse (Clark \& Holquist, 1984). Bakhtin's goal was to overcome simplified linear thinking by introducing a multiplicity of perspectives. This meant, above all, an emphatic rejection of dogmatism (Shotter \& Billig, 1998). Heteroglossia, or the mingling of different language groups, cultures, and classes, was for Bakhtin the ideal condition, guaranteeing a perpetual linguistic and intellectual revolution which guards against the hegemony of any 'official' language in a given society, against ossification and stagnation in thought. Language was to be seen as inherently 'dialogic': it could be grasped only in terms of its inevitable orientation towards another. However, we should not conflate Bakhtin's position with fashionable liberal-multiculturalist notions of diversity which talk about creating a neutral space in which a multitude of narratives can coexist peacefully. Notions of conflict and struggle very much underpin Bakhtin's conception of language ${ }^{11}$. Language is not to be seen as 'expression' or 'reflection' but rather a material social practice where meaning is the outcome of a process of social conflict and dialogue.

Bakhtin's concept of dialogism was most comprehensively formulated in his book on Dostoevsky as a theory of the novel (Bakhtin, 1984) ${ }^{12}$, though its implications extend

\footnotetext{
${ }^{11}$ As Eagleton (1996, p.102) put it, for Bakhtin "the sign was to be seen less as a fixed unit (like a signal) than as an active component of speech, modified and transformed in meaning by the variable social tones, valuations and connotations it condensed within itself in specific social conditions. Since such valuations and connotations were constantly shifting, since the 'linguistic community' was in fact a heterogeneous society composed of many conflicting interests, the sign for Bakhtin was less a neutral element in a given structure than a focus of struggle and contradiction.”

${ }^{12}$ Problems of Dostoevsky's Poetics was the first book that appeared under Bakhtin's own name and was published in 1929. It was also his last appearance in print before disappearing into exile and obscurity.
} 
beyond the world of literary study. Dostoevsky interests Bakhtin because he juxtaposes points of view that are never subordinated to any single or monological perspective: his characters are the bearers of different truths; their voices embody different ethical positions which are tested in the course of a novel and there is a continuous renegotiation of opinion. The discussion of Dostoevsky allows Bakhtin to attack the conventional idea that authors are able to manifest their intentions completely in their works, so that readers can know precisely 'what they meant'. The author is only to be thought of as located in a network of relations and speech genres and is not a point of origin for these things (Burkitt, 1998). It is a drastic step away from the theory of authorship (and communication) represented by Saussure's drawing of the two talking heads, who send out messages to each other that monologically embody their intentions.

Bakhtin's concept of dialogism is based upon a deeply relational understanding of language. With Bakhtin we see a move from 'language' (speech or writing viewed objectively as a chain of signs without a subject) to 'discourse' (language grasped as utterance, as involving speaking and writing subjects and therefore also readers or listeners). Discourse, or 'Speech' as Bakhtin (1986) uses the term, covers many of the aspects of Saussure's parole, for it is concerned with what happens when real people, in all the contingency of their myriad lives, actually speak to each other. But Saussure conceived of the individual language user to be an absolutely free agent with the ability to choose any words to implement a particular intention. Saussure concluded, not surprisingly, that language as used by heterogeneous millions of such willful subjects was unstudiable. Bakhtin, on the other hand, begins by assuming that individual speakers do not have the kind of freedom parole assumes they have. The basic unit for the study of actual speech practice is the "utterance" which, "with all its individuality and creativity, can in no way be regarded as a completely free combination of forms of language, as is supposed, for example, by Saussure” (Bakhtin, 1986, p.82). For Bakhtin it is not simply a matter of asking "what the utterance meant", but of investigating its varied history, as

The second edition of 1963 heralded his re-emergence onto the Soviet publishing scene and his rise to international prominence (see Clark \& Holquist, 1984, p.238ff). 
conflicting social groups, classes, individuals and discourses seek to appropriate it and imbue it with their own meanings.

The key point to make here is that for Bakhtin there are no 'neutral' words and forms. Not only are words and sentences always-already there, but so are the forms for their combination into utterances. There is no language which is not caught up in definite social relationships, and these relationships are in turn part of broader political, ideological and economic systems. Words are multi-accentual rather than frozen in meaning.

As a living, socio-ideological concrete thing... language... lies on the borderline between oneself and the other. The word in language is half someone else's. It becomes 'one's own' only when the speaker populates it with his own intention, his own accent, when he appropriates the word, adapting it to his own semantic and expressive intention... Language... is populated overpopulated - with the intentions of others. (Bakhtin, 1981, p.293-294)

Thus we are never free to impose our unobstructed intention but must always mediate that intention through the intentions of others, beginning with the otherness of the language itself in which we speak: we must enter into a dialogue with others. Language must belong to the Other - to my linguistic community as a whole - before it can belong to me, so that the self comes to its unique articulation in a medium which is always at some level indifferent to it. This does not mean that we cannot make our own point of view understood; it simply implies that our point of view will only emerge through the interaction of our own and others' words as they contend with each other in particular situations. Our speech, that is, all our utterances (including creative works), is filled with others' words, with varying degrees of otherness and varying degrees of 'our-own-ness'. These words of others carry with them their own expression which we always assimilate, rework, and re-accentuate. Our own writing exemplifies the struggle to appropriate others' words in that we have made use of an inordinate amount of direct quotes (thus accentuating a degree of otherness) while (hopefully) preserving the readability and purpose of this text ${ }^{13}$. In the final sections of our paper we will connect Bakhtin's thinking with various issues in OMT we outlined earlier.

\footnotetext{
${ }^{13}$ Juxtaposed, quotations take on novel meanings and enter into mutual debate (Steiner, 2001). Walter Benjamin (1999) is a prime example of an eminent intellectual who was obsessed with quotations. He
} 


\section{Back to OMT: Positions of enunciation}

Nobody is especially concerned about what you say, with what extreme, moderate, radical or conservative positions you adopt, provided that they are compatible with, and can be articulated within, a specific form of discourse. It is just that certain meanings and positions will not be articulable within it... Regional dialects of the discourse, so to speak, are acknowledged and sometimes tolerated, but you must not sound as though you are speaking another language altogether. To do so is to recognize in the sharpest way that critical discourse is power. To be on the inside of the discourse itself is to be blind to this power, for what is more natural and nondominative than to speak one's own tongue? (Eagleton, 1996, p.177)

Bakhtin's deeply relational view of language suggests that our position of enunciation (the subjective position from where we speak) is of great importance in determining what we say and how we are heard. There are no words and forms that can belong to 'no one' and every utterance must be regarded primarily as a response to preceding utterances of a given sphere of speech communication. As Bourdieu (1992, p.47) suggested:

One does not say the same thing in epistemology no matter what the time or place. One develops more or less this or that principle of epistemology according to the state of the unconscious in the given society. For example, in a society dominated by positivism, it is necessary to accentuate constructivism. To put this another way, epistemology is a politics of science (emphasis added).

Whilst, for example, the paradigm debate initially brought a genuine political dimension to the field of OMT, we suggest it now has acquired a rather tired quality as epistemological positions have shifted ${ }^{14}$. Perhaps we should not prolong this particular debate but find new ways of revitalizing and politicizing the field by tapping into or creating new discourses?

regarded quotations in his work as "wayside robbers who leap out, armed, and relieve the idle stroller of his convictions" (p.481). Benjamin understood his first book, The Origin of German Tragic Drama, as essentially a book of quotations with his own writing as secondary and is reported as saying he wanted to write a book with nothing but quotations (Steiner's comment emphasizes the sheer scale of such a project: "Walter Benjamin dreamt of publishing a book composed entirely of quotations. I lack the necessary originality...” p.13).

${ }^{14}$ We refer here, for example, to Elsbach et al. (1999, p.633) who posited: "In 1989, the notion that there is no objective means of assessing the value of a theory would have been viewed as heresy in many of the same corners that it is now accepted as given truth, or at least a plausible and troubling possibility." 
If we push this line of thinking a little further, we can consider the truth-value of a proposition as a matter of its social function. What is enunciated is collapsible to the conditions of enunciation: what matters is not so much what is said, but who says it to whom, from which position (with what, possibly implicit, authority), for what purposes. At the very least we should be aware of the properly symbolic domain of communication in which language is used as a rhetorical device, with its referential meaning clearly subordinated to its performative dimension (of seduction, coercion, etc.). It matters greatly if something is said by the president of the Academy of Management or by a distinguished scholar (e.g., Karl Weick in the field of OMT, Pierre Bourdieu in the field of sociology); arguments suddenly carry more weight if they are published in ASQ, AMR or AMJ. To give some examples: Would there have been such a vigorous debate, described as 'paradigm wars', if anyone of less stature than Jeffrey Pfeffer and John Van Maanen had offered their views on diversity in organization studies? ${ }^{15}$ (Indeed, would anyone else but John Van Maanen have been able to publish such a histrionic response to Jeffrey Pfeffer?) Furthermore, does the reflexive, de-mystifying, stance of eminent scholars which seems to be de rigueur today (cf. Hardy, Phillips \& Clegg, 2001; Weick, 1999) not presuppose a rather elevated a position of enunciation from which these scholars can afford such a deprecating self-designation ${ }^{16}$ ? Finally, when we academics, in a supposedly critical self-reflection, admit to and deplore the 'disconnects' between management research and managers, is the admission of our 'guilt' not the way to preserve our subjective position intact, free from responsibility. In short, there is a way to avoid responsibility by, precisely, too readily assuming one's 'guilt' in an exaggerated way (cf. Žižek, 2000).

\footnotetext{
${ }^{15}$ It is not as if the content of Pfeffer's article was that provocative. He eloquently worded, and thus brought into explicitly codified existence, a tacit uneasiness among mainly American scholars about recent developments in the field. Furthermore, whilst Van Maanen's response got quoted extensively in AMR (e.g. see Fabian's (2000) review), it is interesting to note that it was published in the Crossroads section of Organization Science and not in AMR where Pfeffer's article was published.

${ }^{16}$ Would it be advisable for a young management scholar to describe himself or herself in a job interview as "a practitioner who works with abstract words for a living, reads a lot, and would like to get better at crafting images that capture what I think organizing is all about” (Weick, 1999, p.798)? Our own experience suggests that however honest and de-mystifying this deportment might be, it would be a rather foolhardy stance to adopt for the young scholar in question.
} 


\section{For a return of the political}

Pluralism allows for a multiplicity of coexisting, even competing interpretations, opinions, or approaches; what it does not allow is for the space in which these interpretations are held to take place to be itself considered conflictual... 'Scholarship' and 'research' may investigate conflict, but they do not - or must not - as such partake of it. The function of 'pluralism' is precisely to deny the necessity of conflict, in the name of peacefully coexisting diversity. (Weber, 2001, p.42)

Whilst the problem-solution model of OMT has led to enlightening insights, one should nonetheless insist that the procedures of posing problems and finding solutions to them always and by definition occur within a certain ideological context that determines which problems are crucial and which solutions acceptable. The issue of whom we should be responsible to and in what way can never be assumed as being 'beyond question' Rather, answers to these questions are continuously up for negotiation and are crucially bound up with the identity of the field of organization studies itself (Deetz, 2001). The very fact of joining the Mode 1/Mode 2 discursive universe means entering a socioideological dimension we have to struggle with if we are not to blindly follow a particular political agenda. Consider this extract from Gibbons et al. (1994, p.111): “Another important precondition is to have access to such knowledge and expertise, being able to reconfigure it in novel ways and offer it for sale” (emphasis added). Don't we already have here a conceptualization of knowledge "that is embedded in particular sociotechnical relations of capital and geared towards the production of surplus value”, as Böhm (2002, p.333) points out? Don’t we assume here that "it is the knowledge commodity that should be produced at universities as efficiently and effectively as possible” (ibid.)? The return to the political we advocate means that OMT should not be seen as an independent realm of thought and knowledge, but as a practice that is fully embedded in the wider social relations of capitalist production. Rather than focusing on how academic papers might include implications for practice and/or policy, it requires thinking about ways that academics might become directly involved in policy development processes (Bartunek, 2002). It is an antithetical response to the "obsession with consensus and convergence” Hardy (2002) identified in our field. If we accept that knowledge production can no longer be seen as a result of a neutral, anonymous process but occurs in a politically charged, socio-cultural context of real people with real agendas 
working within important personal relationships and institutional ties (Calás \& Smircich, 1999), then surely it would follow that our field has a strong conflictual dimension. The fact that it has not indicates that a powerful ideological agenda has carried the day, without too many people noticing (or caring). Trying to resolve conflicting viewpoints into a consensus implies a refusal of the truth that some conflicts can be resolved on one side alone. Indeed, the demands that "things should soon return to normal," that we should just "get on with the job of finding empirical evidence," not creating "echo chambers that lead to nowhere," have a profound de-politicizing effect. They presuppose a view of our field as a corporate body, a homogenous social space, and social divisions are like illnesses we should fight. Conflict is seen as destructive and can be avoided by formulating clear rules to be obeyed. But this procedural formalism has the effect of trivializing the actual content of passionately held positions. Thus we find ourselves in agreement with Hinings and Greenwood (2002) when they suggest that the disconnection of organizational studies from its core disciplines (primarily sociology) and its transition to business schools has left many important sociological questions (such as inequality, power and ideology) in perpetual neglect. It has set us on

\footnotetext{
... a path on which the social practice of science as something that involves politics becomes minimized by a singular focus on efficiency and effectiveness. And rather than this being the intended consequence of some grand strategy, it is far more feasible to see this as an unanticipated outcome of the normalization of organization theory within the disciplinary rituals of those institutions that host it ... after all, so much of power involves efficient drilling of routines into a level of subconsciousness where issues of responsibility will not intrude. (Clegg, 2002, p.437)
}

Our plea for a return of the political and an explicit recognition of struggle in OMT does also imply a rejection of cozy pluralism, which can spring from there nothing being much at stake in the first place. A political struggle proper is never simply a rational debate between multiple interests but, simultaneously, the struggle for one's voice to be heard and recognized as that of a legitimate partner in the mainstream of the field. A conflictual perspective by definition requires some kind of connection with others' meanings. To quote Eagleton (1991, p.13): "Those who quite properly emphasize that language is a terrain of conflict sometimes forget that conflict presupposes a degree of mutual agreement: we are not politically conflicting if you hold that patriarchy is an 
objectionable social system and I hold that it is a small town in upper New York state.” We do not see zero-sum conflict as necessarily destructive. There are a range of important contentions (about the nature of research, relations within and between fields...) someone is going to have to win and someone else to lose. Equalizing of all viewpoints can mask a callous indifference. In sketching a vision of a 'dialogical' field, we could do worse than appropriating Deetz's (2001) words:

The conflictual field out of which objects are formed is recovered for creative redetermination constant dedifferentiation and redifferentiation. Given the power of common sense and organizational routines, such rereads require rigor and imagination. The rereadings are formed out of a keen sense of irony, a serious playfulness, and are often guided by the pleasure one has in being freed from the dull compulsions of a world made too easy and too constraining. The point of research in this sense is not to get it right but to challenge the guiding assumptions, fixed meanings and relations, and reopen the formative capacity of human beings in relation to others and the world... (p. 37)

Thus contradiction is to be fully accepted and worked through, something we would prefer to omit in our rush for consistency. Even if a field is permeated by conflict (as, for example, in contradictory theories that try to make sense of a particular phenomenon), this does in no way preclude dialogue between interlocutors - various meanings "all may be juxtaposed to one another, mutually supplement one another, contradict one another and co-exist in the consciousness of real people...” (Bakhtin,1981, p. 292) ${ }^{17}$. Does this incoherence create confusion? Yes! Does this create the impression that the field of organization studies is unclear about what knowledge it is passing on? Yes! There are many who would see this as a serious problem. For example, Van de Ven (1999, p.120121), has a fictional student say:

The classes were echo chambers between contingency theory, resource dependence theory, resource-based theory, institutional theory, transactions costs theory, agency theory, network theory, organizational ecology theory, and complexity theories... You exposed me to all these

\footnotetext{
${ }^{17}$ We would argue that it is precisely the willingness to engage with others' positions that ultimately proves the strength of one's own position. Eco (1992, p.150-151) put it succinctly: "The force of the Copernican revolution is not only due to the fact that it explains some astronomical phenomena better than the Ptolemaic tradition, but also to the fact that it - instead of resenting Ptolemy as a crazy liar - explains why and on which grounds he was justified in outlining his own interpretation.”
} 
theories but gave me no way to sift and winnow among them. How do I know which view is better or worse than another?

Yet, is transparency necessarily a good? Perhaps in communicating our research and teaching our students, sometimes it is good to leave our audience puzzled, uncertain about what is being said, even confused. This is where the real thinking may start. The most corrupting of comforts is intellectual comfort. We see the act of becoming a scholar as one of progressively mastering the field's (possibly contradictory) speech genres. To paraphrase Geertz (as quoted in Horgan, 1997, p.154): progress in OMT may be a corollary of the precision which we vex each other and perpetuate debate in evermore interesting ways. Of course, there is always the danger that such a process will lead not to fruitful dialogue, but to ever more defensiveness, obscurantism, hostility and avoidance (Case, 2003). This is often characterized in the field by one side attacking a 'straw man' set up to represent another side, enabling easy victories but, at the same time, reflecting ignorance on the part of the protagonist (Westwood \& Clegg, 2003). Yet dialogue is essential, and it is an art we need to rediscover. Such a dialogical perspective would offer not just a challenge to orthodoxy (after all, what is orthodox?) but a challenge to the exclusivity of all authorities.

As dialogue is essentially interminable, it leaves us as authors of this text in a somewhat awkward position as we must solve the riddle: How to 'conclude' (thus complying with a generic expectation of closure in our field) without offering a conclusion? Weber's (2001) notion of 'curious' conclusions - “curious... because, in a certain sense, they do not conclude. They should not so much satisfy curiosity as suscitate it” (p.72) encouraged us to let another voice provide our postscript, appropriately enough in a piece where we have appropriated so many words.

Too often pluralism leads to a dull consensus or becomes an instrument for the denial of the claims of others. By contrast, paralogy ${ }^{18}$ implies the refusal of such closure, and the perpetual opening of spaces of contestation. Which is to say that without the critical functioning of theory in the name of a forever open future, we have nothing but repetition, which for many is total silence. Jones (2003, p. 521)

\footnotetext{
${ }^{18}$ Jones (2003) adopts Lyotard’s definition of paralogy as “the search for instabilities” (1984, 53ff.) producing "not the known, but the unknown" (1984 p.60) taken from The Postmodern Condition: A report on knowledge trans. G Bennington and B. Massumi. Minneapolis: University of Minnesota Press.
} 


\section{References}

Astley W.G., Zammuto R.F. 1992. Organization Science, Managers, and Language Games. Organization Science 3: 443-460

Bakhtin M.M. 1981. The Dialogic Imagination: Four Essays by M.M. Bakhtin (C. Emerson, M. Holquist, Trans.). Texas University Press: Austin

Bakhtin M.M. 1984. Problems of Dostoevsky's Poetics (C. Emerson, Trans.). Manchester University Press: Manchester

Bakhtin M.M. 1986. Speech Genres and other Late Essays (V.W. McGee, Trans.). University of Texas: Austin

Bartunek J. M. 2002. The Proper Place of Organizational Scholarship: A Comment on Hinings and Greenwood. Administrative Science Quarterly 47: 422-427.

Benjamin, W. 1999. Selected Writings, Vol. 2, 1927-1940. Belknap Press: Cambridge (MA).

Böhm S. 2002. Movements of Theory and Practice. ephemera: critical dialogues on organization, 2: 328-352.

Boland R.J., Singh. J., Salipante P., Aram J., Fay S.Y., Kanawattanachai P. 2001. Knowledge representations and knowledge transfer. Academy of Management Journal 44: 393-417

Bouchikhi H., Kimberly J.R. 2001. 'It's difficult to innovate': The death of the tenured professor and the birth of the knowledge entrepreneur. Human Relations 54: 77-84

Bourdieu P. 1988. Vive La Crise: For Heterodoxy in Social Science. Theory and Society 17: $773-787$

Bourdieu P. 1992. Thinking About Limits. Theory, Culture \& Society 9: 37-49

Burkitt I. 1998. Bodies of Knowledge: Beyond Cartesian Views of Persons, Selves and Mind. Journal for the Theory of Social Behaviour 28: 63-82

Burrell G. 1996. Normal Science, Paradigms, Metaphors, Discourses and Genealogies of Analysis. In S.R. Clegg, C. Hardy, W.R. Nord (Eds.), Handbook of Organization Studies: 642-658. Sage: London

Burrell G., Morgan G. 1979. Sociological Paradigms and Organisational Analysis. Heinemann: London 
Calás M.B., Smircich L. 1999. Past Postmodernism? Reflections and Tentative Directions. Academy of Management Review 24: 649-671

Case, P. 2003. From Objectivity to Subjectivity: Pursuing Subjective Authenticity in Organizational Research. In R. Westwood, \& S. Clegg (Eds.), Debating Organization: Point-Counterpoint in Organization Studies: 156-179. Oxford: Blackwell.

Chia R. 1996. The Problem of Reflexivity in Organizational Research: Towards a Postmodern Science of Organization. Organization 3: 31-58

Clark K, Holquist M. 1984. Mikhail Bakhtin. Harvard University: Cambridge (MA)

Clegg S.R., Hardy C. 1996. Organizations, Organization and Organizing. In S.R. Clegg, C. Hardy, W.R. Nord (Eds.), Handbook of Organization Studies: 1-29. Sage: London

Clegg S. 2002. "Lives in the Balance" A Comment on Hinings and Greenwood's "Disconnects and Consequences in Organization Theory?". Administrative Science Quarterly. 47: 428-441.

Culler, J. 2001/1981. The Pursuit of Signs. London: Routledge.

Czarniawska B. 2001. Is it Possible to Be a Constructionist Consultant? Management Learning 32: 253-266

Daft R.L., Lewin A.Y. 1990. Can Organization Studies Begin to Break Out of the Normal Science Straitjacket? An Editorial Essay. Organization Science 1: 1-9

De Cock C., Volkmann, C. 2002. Of Language, Limits and Secrets. ephemera: critical dialogues on organization 2: 357-371 (www.ephemeraweb.org)

Deetz S. 1995. The Social Production of Knowledge and the Commercial Artifact. In L.L. Cummings (Ed.), Publishing in the Organizational Sciences: 44-63. Sage: London

Deetz S. 2001. Conceptual Foundations. In F.M. Jablin, L.L. Putnam (Eds.), The New Handbook of Organizational Communication: Advances in Theory, Research, and Methods: 1-46. Sage: London

Eagleton, T. 1991. Ideology: An Introduction. Verso: London.

Eagleton, T. 1996. Literary Theory: An Introduction ( $2^{\text {nd }}$ ed.) Blackwell: Oxford

Eco, U. 1992. Reply. In S. Collini (Ed.), Interpretation and overinterpretation: 139-151. Cambridge: Cambridge University Press. 
Elsbach K.D., Sutton R.I., Whetten D.A. 1999. Perspectives on Developing Management Theory, Circa 1999: Moving from Shrill Monologues to (Relatively) Tame Dialogues. Academy of Management Review 24: 627-633

Fabian H.F. 2000. Keeping the Tension: Pressures to keep the Controversy in the Management Discipline. Academy of Management Review 25: 350-371

Frost P.J. 2002. Afterword. Journal of Management Inquiry 11: 21-22

Fuller S. 2003. Interdisciplinarity: The Loss of Heroic Vision in the Marketplace of Ideas. (http//www.interdisciplines.org/interdisciplinarity/papers/3)

Gibbons, M., Limoges, C., Nowotny, H., Schwartzman, S., Scott, P., \& Trow, M. 1994. The new production of knowledge: The dynamics of science and research in contemporary societies. London: Sage.

Gioia D.A. 2003. Give It Up! Reflections on the Interpreted World (A Commentary on Meckler and Baillie). Journal of Management Inquiry 12: 285-292.

Gioia D.A., Pitre E. 1990. Multiparadigm Perspectives on Theory Building. Academy ofManagement Review 15: 584-60.

Glynn M.A., Barr P.S., Dacin M.T. 2000. Pluralism and the Problem of Variety. Academy of Management Review 25: 726-734

Grey C. 2001. Re-Imagining Relevance: A Response to Starkey and Madan. British Journal of Management 12: S27-S32

Hambrick D. 1994. What if the Academy Actually Mattered? Academy of Management Review 19: 11-17

Hardy C. 2002. On the Edge of a Pluralistic World. Journal of Management Inquiry 11: 16-18

Hardy, C., Phillips, N., \& Clegg, S. 2001. Reflexivity in Organization and Management Theory: A Study of the Production of the Research 'Subject'. Human Relations, 54: 531560.

Hinings C. R., Greenwood R. 2002. Disconnects and Consequences in Organization Theory. Administrative Science Quarterly 47: 411-421

Horgan, J. 1997. The End of Science: Broadway Books

Huff A.S. 2000. Changes in Organizational Knowledge Production. Academy of Management Review 25: 288-293 
Jacques R. 1992. Critique and Theory Building: Producing Knowledge "From the Kitchen". Academy of Management Review 17: 582-606

Jones C. (2003) Theory after the Postmodern Condition. Organization 10: 503-525.

Kilduff M., Mehra A. 1997. Postmodernism and Organizational Research. Academy of Management Review 22: 453-481

Law J. 1999. After ANT: complexity, naming and topology. In J. Law, J. Hassard (Eds.), Actor Network Theory and After: 1-15. Blackwell: London

Lewis M.W., Grimes A.J. 1999. Metatriangulation: Building theory from multiple paradigms. Academy of Management Journal 24: 672-690

Lounsbury M. 2003. The Death of Organization Science. Journal of Management Inquiry 12: 293-298.

March J. 2000. Citigroup's John Reed and Stanford's James March on Management Research and Practice. Academy of Management Executive. 14: 52-64.

Martin. J. 1992. Escaping the Inherent Conservatism of Empirical Organizational Research. In P. Frost, R. Stablein (Eds.), Doing Exemplary Research: 233-239. Sage: London.

Meckler M., Baillie J. 2003a. The Truth About Social Constructionism in Administrative Science. Journal of Management Inquiry 12: 273-284.

Meckler M., Baillie J. 2003b. You Can't Handle the Truth: A Response to Gioia and Lounsbury. Journal of Management Inquiry 12: 299-303.

Mohrman S., Gibson C., Mohrman A. 2001. Doing research that is useful to practice: A model and empirical exploration. Academy of Management Journal 44: 357-375

Mohrman S. 2001. Seize the day: organizational studies can and should make a difference. Human Relations 54: 57-65

Mowday R.T. 1997. Reaffirming Our Scholarly Values. Academy of Management Review 22: 335-345

Parker M. 1992. Post-Modern Organizations or Post-Modern Organization Theory? Organization Studies 13: 1-17

Pettigrew A. 2001. Management Research After Modernism British Journal of Management 12: S61-S70 
Pfeffer J. 1993. Barriers to the Advance of Organizational Science: Paradigm

Development as a Dependent Variable. Academy of Management Review 18: 599-620

Pfeffer J, Sutton RI. 1999. Knowing What to Do is Not Enough: Turning Knowledge into Action. California Management Review 41: 83-108

Poole B. 2001. From phenomenology to dialogue: Max Scheler's phenomenological tradition and Mikhail Bakhtin's development from 'Toward a philosophy of the act' to his study of Dostoevsky. In K Hirschkop, D Shepherd (Eds.), Bakhtin and Cultural Theory, Second ed.: 109-135. Manchester University Press: Manchester

Rynes S.L., Bartunek J.M., Daft R.L. 2001. Across the great divide: Knowledge creation and transfer between practitioners. Academy of Management Journal 44: 340-355

Schultz M., Hatch M.J. 1996. Living With Multiple Paradigms: The Case of Paradigm Interplay in Organizational Culture Studies. Academy of Management Review 21: 529557

Shepherd D. 2001. Bakhtin and the Reader. In K. Hirschkop, D. Shepherd (Eds.), Bakhtin and Cultural Theory, Second ed.: 136-154. Manchester University Press: Manchester

Shotter J., Billig M. 1998. A Bakhtinian Psychology: From Out of the Heads of Individuals and into the Dialogues between Them. In M. Gardiner, M. Mayerfeld Bell (Eds.), Bakhtin and the Human Sciences: 13-29. Sage: London

Starkey K., Madan P. 2001 Bridging the Relevance Gap: Aligning Stakeholders in the Future of Management Research British Journal of Management 12: S3-S26

Steiner G. 2001. Grammars of Creation. Faber \& Faber: London.

Sutton R.I., Staw B.M. 1995. What Theory Is Not. Administrative Science Quarterly 40: 371-384

Taussig M. 1999. Defacement: Public Secrecy and the Labor of the Negative. Stanford University Press: Stanford

Tranfield D., Starkey K. 1998. The Nature, Social Organization and Promotion of Management Research: Towards Policy. British Journal of Management 9: 341-353.

Van de Ven A.H. 1999. The Buzzing, Blooming, Confusing World of Organization and Management Theory: A View from Lake Wobegon University. Journal of Management Inquiry 8: 118-125

Van de Ven A.H. 2002. Strategic Directions for The Academy of Management: This Academy is for You! Academy of Management Review 27: 171-184.

Van Maanen J. 1995. Style as Theory. Organization Science 6: 133-143 
Vickers G. 1995. The Art of Judgment: A Study of Policy Making (Centenary edition ed.). Sage: London

Weaver G.R., Gioia DA. 1994. Paradigms Lost: Incommensurability vs Structurationist Inquiry. Organization Studies 15: 565-590

Weber S. 2001. Institution and Interpretation: Expanded edition. Stanford University Press: Stanford

Weick K.E. 1999. Theory Construction as Disciplined Reflexivity: Tradeoffs in the 90s. Academy of Management Review 24: 797-806

Weick K. E. 2001 Gapping the Relevance Bridge: Fashions Meet Fundamentals in Management Research. British Journal of Management. 12: S71-S75.

Westwood R., Clegg S. 2003. The Discourse of Organization Studies: Dissensus, Politics, and Paradigms. In R. Westwood, S Clegg (Eds.), Debating Organization: PointCounterpoint in Organization Studies: 1 -42. Blackwell: London.

Žižek S. 2000. The Fragile Absolute or Why is the Christian Legacy Worth Fighting For? Verso: London

Žižek, S. 2002/1991 For They Know Not What They Do: Enjoyment as a Political Factor $\left(2^{\text {nd }}\right.$ ed.). Verso: London. 